\title{
TFPI wt Allele
}

National Cancer Institute

\section{Source}

National Cancer Institute. TFPI wt Allele. NCI Thesaurus. Code C97261.

Human TFPI wild-type allele is located in the vicinity of $2 q 32$ and is approximately $90 \mathrm{~kb}$ in length. This allele, which encodes tissue factor pathway inhibitor protein, is involved in the regulation of blood coagulation. 